\title{
Mikropropagasi Tangkai Daun Iles-Iles (Amorphophallus muelleri Blume) Secara In Vitro Dengan Penambahan ZPT BAP dan NAA
}

\author{
Author(s): Fitri Aries Prayana*(1); Djenal ${ }^{(1)}$; Rudi Wardana ${ }^{(1)}$ \\ (1) PS. Teknologi Produksi Tanaman Pangan, Jurusan Produksi Pertanian, Politeknik Negeri Jember \\ * Corresponding author: fitriaries23@gmail.com
}

\begin{abstract}
ABSTRAK
Iles-iles (Amorphophallus muelleri Blume) merupakan jenis tanaman umbi-umbian dari suku Araceaea yang bermanfaat untuk menjadi bahan diversifikasi pangan. Perbanyakan iles-iles membutuhkan waktu lama sehingga dibutuhkan alternatif perbanyakan dengan kultur jaringan. Tujuan penelitian ini adalah mengetahui konsentrasi ZPT BAP dan NAA yang tepat untuk perbanyakan tangkai daun iles-iles. Penelitian dilaksanakan selama 7 bulan sejak bulan Agustus 2016 sampai bulan Februari 2017. Penelitian ini dilaksanakan di Lab. Kuljar Politeknik Negeri Jember. Penelitian ini menggunakan rancangan acak lengkap faktorial dengan 2 faktor, 9 kombinasi perlakuan, dan 6 ulangan. Faktor pertama yakni ZPT BAP terdiri dari 3 taraf yaitu 1; 2; dan 3 mg/l. Faktor kedua yakni ZPT NAA terdiri dari 3 taraf yaitu 0,$1 ; 0,2$; dan $0,3 \mathrm{mg} / \mathrm{l}$. Data dianalisa dengan menggunakan Analysis of Variance lalu diuji lanjut menggunakan BNT taraf 5\% dan 1\%. Hasil penelitian menunjukkan bahwa penambahan $1 \mathrm{mg} / \mathrm{l}$ dan $2 \mathrm{mg} / \mathrm{l}$ BAP berpengaruh terhadap parameter kedinian terbentuknya kalus, kuantitas kalus dan kedinian terbentuknya akar. Perlakuan $0,1 \mathrm{mg} / \mathrm{l}$ NAA berpengaruh terhadap parameter tinggi tunas umur $63 \mathrm{HST}$. Interaksi $1 \mathrm{mg} / 1 \mathrm{BAP}$ dan $0,1 \mathrm{mg} / \mathrm{l} \mathrm{NAA}$ berpengaruh terhadap parameter jumlah tunas umur 63 HST dan tinggi tunas umur 63 HST. Hasil penelitian tersebut menunjukkan bahwa penggunaan ZPT BAP dan NAA yang berbeda mampu memberikan pengaruh terhadap mikropropagasi tangkai daun iles-iles terutama pada pembentukan tunas.
\end{abstract}

\section{Kata Kunci:}

Amorphophallus muelleri Blume;

BAP;

Mikropropagasi;

NAA;

Zat pengatur tumbuh;

\section{Keywords:}

Amorphophallus muelleri B;

$B A P$;

Micropropagation;

$N A A$;

Plant growth regulator;

\section{ABSTRACT}

Iles-iles (Amorphophallus muelleri Blume) is a tuber plant belongs to the Araceae which has profit to be food diversification. Cultivated of iles-iles need long time, so an alternative cultivation by tissue culture needed. The research aims to know concentration of plant growth regulator BAP and NAA exactly for micropropagation leaf petioles of iles-iles. The research was conducted for seven months from August 2016 to February 2017. The place of research was in the Tissue Culture Laboratory, State Polytechnic of Jember. This study uses a completely randomize design (CRD) with 2 factors, each factors contain 2 level, and 6 replications. The first factor is BAP consists of three levels: 1,2 , and $3 \mathrm{mg} / \mathrm{l}$. The second factor is NAA consist of three levels: $0.1,0.2$, and $0.3 \mathrm{mg} / \mathrm{l}$. Data were analyzed by using Analysis of Variance, $L S D$ level $5 \%$ and $1 \%$. The experiment showed that the addition of $1 \mathrm{mg} / \mathrm{l}$ and $2 \mathrm{mg} / \mathrm{l} \mathrm{BAP}$ gave effect in parameters time of callus induction, quantity of callus and time of root induction. Treatment $0,1 \mathrm{mg} / \mathrm{l} N A A$ gave effect in parameter shoot height at $63 \mathrm{DAP}$. The interaction between $1 \mathrm{mg} / \mathrm{l} B A P$ and $0,1 \mathrm{mg} / \mathrm{l} N A A$ gave effect in parameters shoot total at 63 DAP and shoot height at 63 DAP. The experiment showed that implementation of different plant growth regulator between BAP and NAA caused response on micropropagation leaf petioles of iles-iles especially in shoot formation. 


\section{PENDAHULUAN}

Iles-iles (Amorphophallus muelleri Blume) menjadi salah satu jenis umbiumbian yang memiliki potensi untuk dikembangkan menjadi bahan diversifikasi pangan. Iles-iles berasal dari suku Araceaea. Iles-iles belum banyak ditanam di Indonesia. Tanaman ini mampu hidup secara liar di hutan. Iles-iles masih sangat sedikit dimanfaatkan untuk bidang industri pangan maupun non pangan. Umbi iles-iles dapat diolah menjadi tepung yakni tepung mannan yang mengandung glukomannan sangat tinggi (40-65) \% sehingga berpotensi untuk dijadikan makanan diet, memiliki banyak serat dan non kolesterol (Imelda et al., 2007).

Tepung Mannan atau tepung Konjac mengandung Glukomannan yang tinggi dari pada bagian lain yang ada dalam tepung. Tepung Mannan biasa digunakan menjadi Konyaku (sejenis tahu) dan Shirataki (sejenis mie) sebagai makanan di negara Jepang atau sebagai bahan baku agar-agar dan gelatin. Pemanfaatan ilesiles untuk industri non pangan yakni dapat dijadikan sebagai bahan perekat tekstil, cat, bahan negatif film, bahan isolasi, pita seluloid dan bahan kosmetika (Imelda et al., 2007).

Iles-iles di Indonesia sebagian besar diekspor ke Jepang, tetapi belum mampu untuk memenuhi permintaan oleh karena itu peluang ekspornya masih tinggi, sehingga dibutuhkan suatu teknik untuk memperbanyak bibit secara efektif dan efisien melalui kultur jaringan yang mampu menghasilkan bibit dalam jumlah banyak, secara cepat, seragam dan berkelanjutan (Imelda, et al., 2008).

Regenerasi tanaman iles-iles secara alamiah melalui organ vegetatifnya yakni umbi atau potongan umbi, bulbil (umbi generatif) dan stek daun sedangkan secara generatif menggunakan biji (Hetterscheid \& Ittenbach, 1996). Tanaman iles-iles memiliki biji triploid apomiksis yang bukan hasil dari tetuanya sehingga keragamannya terbatas (Imelda et al., 2008).

Kultur jaringan sebagai suatu teknik yang berguna untuk mengurangi patogen dengan memilih bagian (sel) yang tidak mengandung patogen sistemik seperti virus, dapat menumbuhkan bagian atau sel tanaman tersebut dan meregenerasikannya menjadi tanaman sempurna dan sehat (Karjadi, 2016).

Pemberian sitokinin dan auksin yang seimbang menentukan pertumbuhan dan morfologi tanaman secara in vitro (Armini et al., 1992). Sitokinin berperan dalam pengaturan pembelahan sel, morfogenesis dan digunakan untuk merangsang pembentukan tunas, metabolisme sel, merangsang sel dorman utamanya untuk pembelahan sel. BAP merupakan ZPT golongan sitokinin. Auksin berperan dalam pertumbuhan dan morfogenesis dan digunakan untuk memanjangnya sel, membentuk akar adventif dan NAA merupakan ZPT golongan auksin (Karjadi \& Buchory, 2008).

Penelitian ini mencoba untuk mengkaji zat pengatur tumbuh BAP dan NAA yang tepat untuk perbanyakan (mikropropagasi) tangkai daun iles-iles secara in vitro guna memperoleh bibit ilesiles dalam jumlah banyak. Hasil penelitian yang didapatkan diharapkan dapat memberikan informasi mengenai perbanyakan tanaman Iles-iles (Amorphophallus muelleri Blume) dalam jumlah banyak, seragam dan cepat serta tetap memperhatikan efisiensi dan efektifitas media yang digunakan.

\section{BAHAN DAN METODE}

Penelitian ini dilaksanakan di Lab. Kuljar, Politeknik Negeri Jember. Suhu ruang $23,5^{\circ} \mathrm{C}$, kelembaban $52 \mathrm{RH}$, intensitas cahaya 1541 Lux dan lama penyinaran 16 jam. Penelitian dimulai pada bulan Agustus 2016 sampai Februari 2017.

Bahan yang digunakan dalam penelitian antara lain eksplan tangkai daun 
(petiole) iles-iles, Media MS, ZPT BAP dan NAA, agar Swallow, gula, aquades serta $\mathrm{NaOH}$ dan $\mathrm{HCl}$.

Penelitian ini menggunakan Rancangan Acak Lengkap (RAL) faktorial dengan 2 faktor, 9 kombinasi perlakuan dan 6 ulangan. Faktor pertama adalah ZPT BAP $1 \mathrm{mg} / \mathrm{l}\left(\mathrm{B}_{1}\right), 2 \mathrm{mg} / \mathrm{l}\left(\mathrm{B}_{2}\right)$ dan $3 \mathrm{mg} / \mathrm{l}$ (B3). Faktor kedua adalah ZPT NAA 0,1 $\mathrm{mg} / 1\left(\mathrm{~N}_{1}\right), 0,2 \mathrm{mg} / \mathrm{l}\left(\mathrm{N}_{2}\right)$, dan $0,3 \mathrm{mg} / \mathrm{l}\left(\mathrm{N}_{3}\right)$.

Penelitian ini menggunakan perlakuan kombinasi zat pengatur tumbuh BAP dan NAA, terdapat 9 kombinasi dengan 6 kali pengulangan dan 1 sampel sehingga diperoleh 54 unit percobaan. Zat pengatur tumbuh sesuai perlakuan ditambahkan ke dalam media MS0 yang kemudian disterilkan dengan autoclave pada suhu $121^{\circ} \mathrm{C}$ dan tekanan 17,5 psi selama 30 menit. Botol-botol kultur media yang telah steril kemudian disimpan dan ditata rapi pada lemari penyimpanan media.

Eksplan tangkai daun diperoleh dari eksplan yang sudah steril. Eksplan tangkai daun dipotong dengan ukuran $1 \mathrm{~cm}$. Selanjutnya, proses penanaman eksplan tangkai daun menggunakan media MS0. Proses penanaman dilakukan di dalam laminar air flow (LAF) yang sebelumnya telah dibersihkan menggunakan sinar UV. Pada laminar air flow diletakkan alat-alat inokulasi. Alat tersebut disemprot menggunakan alkohol 96\% kemudian dipanaskan pada bunsen burner selama 1-2 menit. Tangkai daun siap tanam dikeluarkan dari botol sterilisasi dan diletakkan pada cawan petri steril yang telah dilapisi kertas saring steril untuk menyerap aquades.

Eksplan tangkai daun diletakkan selama 2 minggu di dalam MS0, apabila tidak terjadi kontaminasi, eksplan siap ditanaman pada media perlakuan. Eksplan tangkai daun diletakkan pada media yang ada di dalam botol kultur yang mengandung ZPT BAP dan NAA dengan konsentrasi yang telah disebutkan dengan posisi horizontal. Simpan di ruang inkubasi dengan suhu ruang $23,5^{\circ} \mathrm{C}$ dan kelembaban 52 RH intensitas cahaya 1541 Lux, dengan lama penyinaran 16 jam.

Pengamatan dilakukan untuk mendapatkan data dari beberapa parameter, antara lain: kedinian terbentuknya kalus (HST), kualitas kalus umur 63 HST. Pengamatan kualitas kalus menggunakan skoring: $1=$ belum ada kalus; 2= kalus remah; 3= kalus intermediet; 4= kalus kompak. Kuantitas kalus umur 63 HST. Pengamatan kuantitas kalus menggunakan skoring: $1=$ belum ada kalus; 2= kalus sedikit $(<1$ kali ukuran eksplan); $3=$ kalus sedang (=1 kali ukuran eksplan); 4= kalus banyak ( $>1$ kali ukuran eksplan). Kedinian terbentuknya akar (HST), jumlah akar umur 84 HST, panjang akar umur 84 HST $(\mathrm{cm})$, kedinian terbentuknya tunas HST, jumlah tunas umur $63 \mathrm{HST}$, serta tinggi tunas umur 63 HST (cm).

Data hasil pengamatan dianalisis menggunakan ANOVA (Analysis of Variance). Data akan diuji lanjut dengan uji BNT 5\% atau 1\% jika hasil analisa menunjukkan perbedaan nyata atau sangat nyata.

\section{HASIL DAN PEMBAHASAN Kedinian Terbentuknya Kalus}

Penggunaan zat pengatur tumbuh BAP menunjukkan hasil yang berbeda sangat nyata pada parameter kedinian terbentuknya kalus (Tabel 1).

Tabel 1. Rata-rata Kedinian Terbentuknya Kalus (HST)

\begin{tabular}{ll}
\hline BAP & $\begin{array}{l}\text { Kedinian Terbentuknya } \\
\text { Kalus }\end{array}$ \\
\hline $1 \mathrm{mg} / 1$ & $25,00 \mathrm{a}$ \\
$2 \mathrm{mg} / 1$ & $19,11 \mathrm{a}$ \\
$3 \mathrm{mg} / \mathrm{l}$ & $9,33 \mathrm{~b}$ \\
\hline
\end{tabular}

Keterangan:

Setiap dua perlakuan yang mempunyai huruf yang sama dinyatakan tidak berbeda nyata pada taraf $1 \%$. 
Hasil tersebut dibuktikan dengan perlakuan $3 \mathrm{mg} / \mathrm{l}$ BAP sebagai perlakuan terbaik untuk menumbuhkan kalus yang diuji dengan BNT 1\%.

Penambahan auksin dan sitokinin dalam jumlah yang seimbang akan mendorong pembentukan kalus (Ikeuchi et al., 2013). Morfogenesis yang terjadi pada kultur jaringan tanaman sebagian besar dipengaruhi oleh perbandingan konsentrasi sitokinin dan auksin yang ada dalam media. Inisiasi akar pada planlet, embriogenesis, dan inisiasi kalus umumnya terjadi apabila perbandingan konsentrasi auksin terhadap sitokinin lebih tinggi. Terdapat dua hal yang sangat menentukan keberhasilan kultur jaringan, yakni asal eksplan dan media kultur yang digunakan (Karjadi \& Buchory, 2008).

Penggunaan eksplan tangkai daun yang masih muda yang memiliki jaringan meristematik cukup menguntungkan karena akan lebih mudah membentuk kalus dibanding dengan penggunaan eksplan yang sudah tua yang memiliki jaringan yang sudah tidak meristematik. Pembentukan kalus iles-iles tidak banyak dipengaruhi oleh zat pengatur tumbuh eksogen (dari luar) tanaman namun cukup menggunakan zat pengatur tumbuh endogen (dari dalam) tanaman.

\section{Kualitas Kalus Umur 63 HST}

Kualitas kalus diukur menggunakan skoring yang terdiri dari parameter belum ada kalus, kalus remah, kalus intermediet dan kalus kompak. Parameter pengamatan belum ada kalus dan kalus kompak didapatkan dari sumber Andarwulan et al., (1999) dan parameter kalus remah dan kalus intermediet didapatkan dari sumber (Turhan, 2004).

Berdasarkan hasil uji BNT pada taraf $1 \%$ dapat diketahui bahwa interaksi pada kombinasi antara BAP dan NAA berbeda tidak nyata. Perlakuan B1N1, B2N1, $\mathrm{B} 1 \mathrm{~N} 2, \quad \mathrm{~B} 1 \mathrm{~N} 3, \quad \mathrm{~B} 3 \mathrm{~N} 3$ dan $\mathrm{B} 2 \mathrm{~N} 2$ mempunyai huruf notasi yang sama yang artinya bahwa perlakuan tersebut memiliki rerata angka yang tidak jauh berbeda karena kelima perlakuan termasuk dalam kategori kualitas kalus yang kompak dan intermediet.

Tabel 2. Rata-rata Kualitas Kalus Umur 63 HST

\begin{tabular}{ccc}
\hline \multicolumn{2}{c}{$\begin{array}{c}\text { Kombinasi } \\
\text { Perlakuan }\end{array}$} & $\begin{array}{c}\text { Kualitas Kalus } \\
\text { Umur 63 HST }\end{array}$ \\
\cline { 1 - 2 } BAP & NAA & \\
\hline $1 \mathrm{mg} / 1$ & $0,1 \mathrm{mg} / 1$ & $3,50 \mathrm{a}$ \\
$2 \mathrm{mg} / 1$ & $0,1 \mathrm{mg} / 1$ & $3,33 \mathrm{a}$ \\
$1 \mathrm{mg} / 1$ & $0,2 \mathrm{mg} / 1$ & $3,17 \mathrm{a}$ \\
$1 \mathrm{mg} / 1$ & $0,3 \mathrm{mg} / 1$ & $2,83 \mathrm{a}$ \\
$3 \mathrm{mg} / 1$ & $0,3 \mathrm{mg} / 1$ & $2,83 \mathrm{a}$ \\
$2 \mathrm{mg} / 1$ & $0,2 \mathrm{mg} / 1$ & $2,67 \mathrm{a}$ \\
$2 \mathrm{mg} / 1$ & $0,3 \mathrm{mg} / 1$ & $2,33 \mathrm{ab}$ \\
$3 \mathrm{mg} / 1$ & $0,2 \mathrm{mg} / 1$ & $2,17 \mathrm{ab}$ \\
$3 \mathrm{mg} / 1$ & $0,1 \mathrm{mg} / 1$ & $1,00 \mathrm{~b}$ \\
\hline
\end{tabular}

\section{Keterangan:}

Setiap dua perlakuan yang mempunyai huruf yang sama dinyatakan tidak berbeda nyata pada taraf $1 \%$.

Kualitas kalus kompak dinyatakan baik untuk digunakan menjadi bahan penghasil metabolit sekunder (Indah \& Ermavitalini, 2013), sedangkan kalus remah dinyatakan baik bagi kultur suspensi yang digunakan untuk memperbanyak jumlah kalus (Andaryani, 2010). Kualitas kalus belum kompak namun tidak remah dikategorikan sebagai kalus intermediet atau gabungan antara kalus remah dan kompak. Menurut (Pierik, 1987) tekstur kalus dapat bervariasi mulai dari kompak hingga remah bergantung pada jenis tanaman yang digunakan, komposisi media, zat pengatur tumbuh dan kondisi lingkungan tumbuh.

\section{Kuantitas Kalus Umur 63 HST}

Kuantitas kalus diukur menggunakan skoring dari Andarwulan et al., (1999) yang terdiri dari parameter belum ada kalus, kalus sedikit $(<1$ kali ukuran eksplan), kalus sedang (=1 kali ukuran eksplan) dan kalus banyak ( $>1$ kali ukuran eksplan). Hasil uji BNT 1\% pada 
parameter kualitas kalus umur 63 HST menunjukkan bahwa faktor BAP berbeda sangat nyata dan perlakuan terbaik yakni 1 dan $2 \mathrm{mg} / \mathrm{l} \mathrm{BAP}$.

Tabel 3. Rata-rata Kuantitas Kalus Umur 63 HST

\begin{tabular}{cc}
\hline BAP & Kuantitas Kalus Umur 63 HST \\
\hline $1 \mathrm{mg} / \mathrm{l}$ & $3,28 \mathrm{a}$ \\
$2 \mathrm{mg} / \mathrm{l}$ & $3,22 \mathrm{a}$ \\
$3 \mathrm{mg} / \mathrm{l}$ & $1,89 \mathrm{~b}$ \\
\hline
\end{tabular}

Keterangan:

Setiap dua perlakuan yang mempunyai huruf yang sama dinyatakan tidak berbeda nyata pada taraf $5 \%$.

Perlakuan 1 dan $2 \mathrm{mg} / \mathrm{l}$ terbukti mampu menambah massa dari eksplan tangkai daun dan kalus memiliki ukuran yang besar. Pengamatan kuantitas kalus umur 63 HST menunjukkan bahwa kalus mengalami pertambahan volume karena terjadi pembesaran sel dan secara keseluruhan ukuran kalus menjadi lebih besar dari ukuran awal yakni 1 kali lebih besar. Perbedaaan kuantitas kalus terjadi karena eksplan tangkai daun yang digunakan memiliki kepekaan dan daya serap terhadap media yang berbeda serta adanya pengaruh dari zat pengatur tumbuh yang diberikan. Kecepatan sel dalam membelah akan mempengaruhi volume sel (Rahayu et al., 2003). Perlakuan terakhir yang belum menunjukkan adanya tandatanda berkalus adalah perlakuan B3N1. Perlakuan B3N1 menunjukkan tanda-tanda berubah warna menjadi kecoklatan (browning) pada minggu ke-3 setelah tanam hingga menjadi hitam (blackening) pada minggu ke-12 setelah tanam.

\section{Kedinian Terbentuknya Akar}

Kedinian terbentuk akar diamati setiap hari dimulai pada minggu ke-1 setelah tanam hingga minggu ke-10. Pertama kali kalus muncul di minggu ke-3 atau pada hari ke-21. Hasil analisa sidik ragam terhadap kedinian terbentuknya akar memperlihatkan bahwa F-hitung BAP (B) lebih besar dari F-tabel 5\%. Hal ini berarti penggunaan zpt BAP berpengaruh nyata terhadap kedinian terbentuknya akar oleh karena itu faktor B diuji lanjut dengan uji BNT 5\%.

Tabel 4. Rata-rata Kedinian Terbentuknya Akar (HST)

\begin{tabular}{cc}
\hline BAP & Kedinian Terbentuknya Akar \\
\hline $1 \mathrm{mg} / 1$ & $27,44 \mathrm{a}$ \\
$2 \mathrm{mg} / 1$ & $24,83 \mathrm{a}$ \\
$3 \mathrm{mg} / 1$ & $11,67 \mathrm{~b}$ \\
\hline
\end{tabular}

Keterangan:

Setiap dua perlakuan yang mempunyai huruf yang sama dinyatakan tidak berbeda nyata pada taraf 5\%.

Pemberian sitokinin berupa BAP dan auksin berupa NAA sangat mempengaruhi kedinian terbentuknya akar. Auksin berperan dalam pertumbuhan dan morfogenesis dan digunakan untuk memanjangnya sel, membentuk akar adventif (Karjadi \& Buchory, 2008). Penggunaan auksin berupa NAA dengan konsentrasi yang rendah tidak memberikan pengaruh terhadap pertumbuhan akar.

Konsentrasi yang digunakan dimulai dari $0,1 \mathrm{mg} / 1,0,2 \mathrm{mg} / \mathrm{l}$ dan $0,3 \mathrm{mg} / \mathrm{l}$. Inisiasi akar pada planlet akan terjadi apabila konsentrasi auksin lebih tinggi dibanding sitokinin. Hal ini terbukti dengan komposisi sitokinin berupa BAP yang konsentrasinya lebih tinggi dibanding NAA yakni, $1 \mathrm{mg} / 1,2 \mathrm{mg} / \mathrm{l}$, dan $3 \mathrm{mg} / \mathrm{l}$ oleh karena itu, perbedaan konsentrasi zat pengatur tumbuh menyebabkan pertumbuhan akar kurang signifikan.

\section{Jumlah Akar Umur 84 HST}

Tabel 5. Rata-rata Jumlah Akar Umur 84 HST

\begin{tabular}{cc}
\hline BAP & Jumlah Akar Umur 84 HST \\
\hline $1 \mathrm{mg} / 1$ & $7,94 \mathrm{a}$ \\
$2 \mathrm{mg} / 1$ & $5,39 \mathrm{ab}$ \\
$3 \mathrm{mg} / \mathrm{l}$ & $1,50 \mathrm{~b}$ \\
\hline
\end{tabular}

Keterangan:

Setiap dua perlakuan yang mempunyai huruf yang sama dinyatakan tidak berbeda nyata pada taraf $5 \%$. 
Hasil analisa sidik ragam terhadap jumlah akar memperlihatkan bahwa Fhitung faktor $\mathrm{B}$ lebih besar dari $\mathrm{F}$ tabel $1 \%$. Hal ini berarti penggunaan BAP berpengaruh nyata terhadap kedinian terbentuknya akar oleh karena itu faktor B diuji lanjut dengan uji BNT 1\%.

Penelitian ini menggunakan auksin berupa NAA cukup sedikit yakni $0,1 \mathrm{mg} / \mathrm{l}$, $0,2 \mathrm{mg} / 1$ dan $0,3 \mathrm{mg} / 1$ namun pada jumlah yang terkecil yakni $0,1 \mathrm{mg} / 1 \mathrm{mampu}$ membuat eksplan mempunyai akar yang banyak. Hal ini dibuktikan dengan rerata pertambahan jumlah akar terbaik ada pada perlakuan B1N1 sedangkan interaksi antara BAP dan NAA tidak berbeda nyata. Hal ini dapat dilihat dengan rerata jumlah akar pada perlakuan kombinasi BAP dan NAA.

Menurut (George et al., 1984) pemberian ZPT auksin dan sitokinin yang berasal dari luar (eksogen) dapat meningkatkan biosintesis hormon alami. Zat pengatur tumbuh umumnya akan mempunyai pengaruh yang baik pada konsentrasi yang relatif rendah karena auksin endogen (dari dalam) pada iles-iles mampu merangsang akar iles-iles sehingga penggunaan zat pengatur tumbuh (hormon eksogen) dibutuhkan dalam jumlah yang relatif sedikit.

\section{Panjang Akar Umur 84 HST}

Hasil analisa sidik ragam terhadap panjang akar memperlihatkan bahwa Fhitung faktor $\mathrm{B}$ lebih besar dari $\mathrm{F}$ tabel $1 \%$. Hasil uji BNT 1\% menunjukkan berbeda tidak nyata. B1 (1 mg/l BAP) dan B2 (2 mg/l BAP) memberikan respon dengan notasi yang sama sedangkan B2 $(2 \mathrm{mg} / 1$ BAP) dan B3 (3 mg/l BAP) memberikan respon dengan notasi yang sama.

Penggunaan zpt BAP 1 dan $2 \mathrm{mg} / 1$ BAP mampu menambah panjang akar eksplan iles-iles. Konsentrasi BAP yang semakin meningkat, akan membuat perpanjangan akar terhambat. Konsentrasi sitokinin yang tinggi lebih cocok diaplikasikan untuk pertumbuhan tunas. Perbandingan sitokinin (BAP) dan auksin (NAA) yang digunakan cukup seimbang.

Semakin tinggi konsentrasi auksin yang diberikan akan mengakibatkan permeabilitas sel-sel pada eksplan sehingga akan mendorong munculnya primordial akar pada eksplan (Nisa \& Rodinah, 2005). Namun, pada penelitian ini jumlah sitokinin lebih tinggi dibanding jumlah auksin sehingga lebih efektif untuk menumbuhkan tunas.

Tabel 6. Rata-rata Panjang Akar (cm) pada Umur 84 HST

\begin{tabular}{lc}
\hline BAP & Panjang Akar Umur 84 HST \\
\hline $1 \mathrm{mg} / 1$ & $2,72 \mathrm{a}$ \\
$2 \mathrm{mg} / 1$ & $1,61 \mathrm{ab}$ \\
$3 \mathrm{mg} / 1$ & $0,53 \mathrm{~b}$ \\
\hline
\end{tabular}

Keterangan:

Setiap dua perlakuan yang mempunyai huruf yang sama dinyatakan tidak berbeda nyata pada taraf $5 \%$.

\section{Kedinian Terbentuknya Tunas}

Pemberian zat pengatur tumbuh BAP dan NAA memberikan hasil yang berbeda tidak nyata (no significant) terhadap parameter kedninian terbentuknya kalus. Pengamatan terhadap kedinian kalus dilakukan pada 7 hari setelah tanam. Jumlah eksplan yang tidak muncul tunas cukup banyak, dari 54 botol yang diamati, 36 botol tidak tumbuh tunas atau sekitar $66,67 \%$. Eksplan muncul pertama kali pada minggu ke-9 namun kemunculannya tidak serentak.

Pemanfaatan BAP sebagai ZPT, sangat sesuai untuk menumbuhkan tunas in vitro (Imelda et al., 2008) namun penggunaannya dalam konsentrasi yang rendah mampu menyebabkan eksplan lama untuk bertunas. Hal ini terbukti dengan pernyataan yang dikemukakan oleh (Imelda et al., 2007) bahwa pada iles-iles, penggunaan BAP tunggal yakni dengan konsentrasi $1 \mathrm{mg} / \mathrm{l}$ mampu menghasilkan banyak tunas, namun membutuhkan waktu relatif lama. 
Hasil analisa sidik ragam terhadap jumlah tunas umur 63 HST memperlihatkan bahwa F-hitung faktor B lebih besar dari $\mathrm{F}$ tabel 1\%.

\section{Jumlah Tunas Umur 63 HST}

Tabel 7. Rata-rata Jumlah Tunas Umur 63 HST

\begin{tabular}{ccc}
\hline \multicolumn{2}{c}{$\begin{array}{c}\text { Kombinasi } \\
\text { Perlakuan }\end{array}$} & $\begin{array}{c}\text { Jumlah Tunas } \\
\text { Umur 63 HST }\end{array}$ \\
\cline { 1 - 2 } BAP & NAA & \\
\hline $1 \mathrm{mg} / 1$ & $0,1 \mathrm{mg} / 1$ & $1,08 \mathrm{a}$ \\
$1 \mathrm{mg} / 1$ & $0,2 \mathrm{mg} / 1$ & $0,79 \mathrm{~b}$ \\
$1 \mathrm{mg} / 1$ & $0,3 \mathrm{mg} / 1$ & $0,71 \mathrm{~b}$ \\
$2 \mathrm{mg} / 1$ & $0,1 \mathrm{mg} / 1$ & $0,71 \mathrm{~b}$ \\
$2 \mathrm{mg} / 1$ & $0,2 \mathrm{mg} / 1$ & $0,71 \mathrm{~b}$ \\
$2 \mathrm{mg} / 1$ & $0,3 \mathrm{mg} / 1$ & $0,71 \mathrm{~b}$ \\
$3 \mathrm{mg} / 1$ & $0,1 \mathrm{mg} / 1$ & $0,71 \mathrm{~b}$ \\
$3 \mathrm{mg} / 1$ & $0,2 \mathrm{mg} / 1$ & $0,71 \mathrm{~b}$ \\
$3 \mathrm{mg} / 1$ & $0,3 \mathrm{mg} / 1$ & $0,71 \mathrm{~b}$ \\
\hline
\end{tabular}

Keterangan: Setiap dua perlakuan yang mempunyai huruf yang sama dinyatakan tidak berbeda nyata pada taraf $5 \%$.

Selain itu, Hasil uji BNT 5\% menunjukkan pengaruh antara penggunaan ZPT BAP dan NAA terhadap parameter jumlah tunas. B1N1 (1 mg/l BAP + 0,1 mg/l NAA) memberikan respon lebih tinggi dalam hal jumlah tunas terbanyak yakni 1,08. Interaksi yang diberikan oleh perlakuan kedua hingga kesembilan tidak berbeda nyata pada taraf 5\% karena diikuti oleh notasi yang sama. Hal ini karena pada 63 HST atau minggu ke-9 tunas baru muncul pada beberapa eksplan. Pertumbuhan tunas tidak serentak dan belum signifikan. Penggunaan sitokinin berupa BAP sangat efektif untuk pertambahan jumlah tunas seperti yang dikemukakan oleh (Altman \& Loberant, 1998), menyatakan bahwa pembentukan tunas secara in vitro dipengaruhi oleh adanya sitokinin yang tinggi pada media kultur, dan jenis sitokinin yang paling efektif adalah BAP.

\section{Tinggi Tunas Umur 63 HST}

Hasil analisa sidik ragam terhadap tinggi tunas umur 63 HST memperlihatkan bahwa F-hitung faktor B lebih besar dari F tabel $5 \%$.

Tabel 8. Rata-rata Tinggi Tunas $(\mathrm{cm})$ pada Umur 63 HST

\begin{tabular}{ccc}
\hline \multicolumn{2}{c}{$\begin{array}{c}\text { Kombinasi } \\
\text { Perlakuan }\end{array}$} & $\begin{array}{c}\text { Tinggi Tunas Umur } \\
\text { 63 HST }\end{array}$ \\
\cline { 1 - 2 } BAP & NAA & \\
\hline $1 \mathrm{mg} / 1$ & $0,1 \mathrm{mg} / 1$ & $0,97 \mathrm{a}$ \\
$1 \mathrm{mg} / 1$ & $0,2 \mathrm{mg} / 1$ & $0,72 \mathrm{~b}$ \\
$1 \mathrm{mg} / 1$ & $0,3 \mathrm{mg} / 1$ & $0,71 \mathrm{~b}$ \\
$2 \mathrm{mg} / 1$ & $0,1 \mathrm{mg} / 1$ & $0,71 \mathrm{~b}$ \\
$2 \mathrm{mg} / 1$ & $0,2 \mathrm{mg} / 1$ & $0,71 \mathrm{~b}$ \\
$2 \mathrm{mg} / 1$ & $0,3 \mathrm{mg} / 1$ & $0,71 \mathrm{~b}$ \\
$3 \mathrm{mg} / 1$ & $0,1 \mathrm{mg} / 1$ & $0,71 \mathrm{~b}$ \\
$3 \mathrm{mg} / 1$ & $0,2 \mathrm{mg} / 1$ & $0,71 \mathrm{~b}$ \\
$3 \mathrm{mg} / 1$ & $0,3 \mathrm{mg} / 1$ & $0,71 \mathrm{~b}$ \\
\hline
\end{tabular}

Keterangan: Setiap dua perlakuan yang mempunyai huruf yang sama dinyatakan tidak berbeda nyata pada taraf $5 \%$.

Hasil uji BNT 5\% menunjukkan adanya interaksi antara penggunaan zpt BAP dan NAA terhadap jumlah tunas. B1N1 (1 mg/l BAP + 0,1 mg/l NAA) memberikan respon lebih tinggi dalam hal tinggi tunas terpanjang yakni $0,97 \mathrm{~cm}$. Pertumbuhan tunas tidak serentak dan belum signifikan. Pemberian zpt BAP dan NAA berpengaruh terhadap tinggi tunas umur 63 HST.

(George \& Sherrington, 1984) berpendapat bahwa media perbanyakan in vitro biasanya menggunakan ZPT sitokinin yakni BAP. BAP banyak digunakan untuk membentuk tunas dan mendorong proses pembelahan sel. Parameter tunas tertinggi dihasilkan dari konsentrasi $1 \mathrm{mg} / \mathrm{l}$ dan NAA konsentrasi $1 \mathrm{mg} / \mathrm{l}$. 


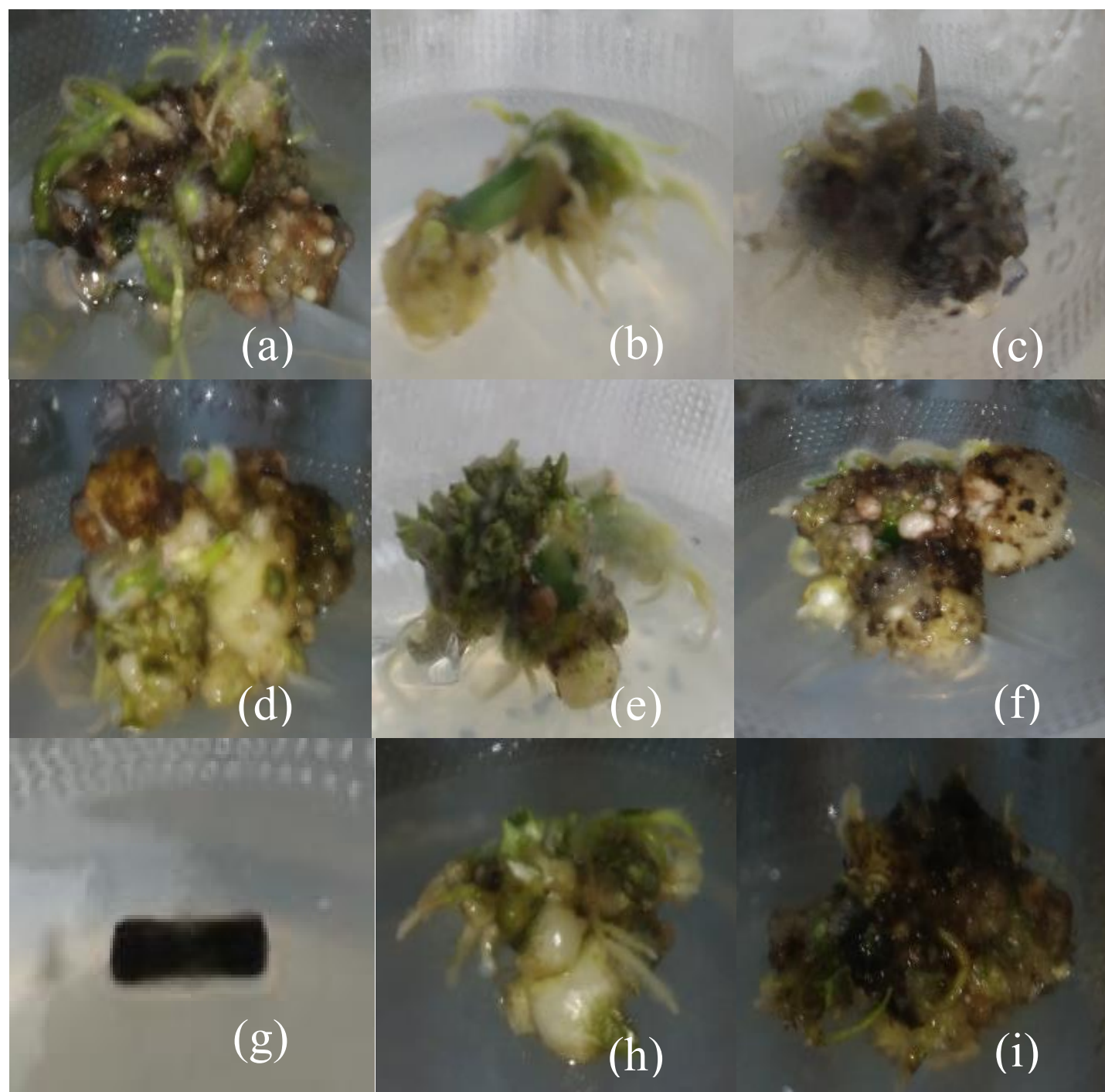
(a) B1N1 (1 mg/l BAP + 0,1 mg/1 NAA)
(b) B1N2 (1 mg/l BAP + 0,2 mg/1 NAA)
(f) $\mathrm{B} 2 \mathrm{~N} 3(2 \mathrm{mg} / 1 \mathrm{BAP}+0,3 \mathrm{mg} / 1 \mathrm{NAA})$
(c) B1N3 (1 mg/1 BAP + 0,3 mg/1 NAA)
(g) B3N1 (3 mg/l BAP + 0,1 mg/l NAA)
(d) B2N1 (2 mg/l BAP + 0,1 mg/l NAA)
(h) B3N2 (3 mg/l BAP + 0,2 mg/l NAA)
(e) B2N2 (2 mg/l BAP + 0,2 mg/1 NAA)
(i) $\mathrm{B} 3 \mathrm{~N} 3(3 \mathrm{mg} / 1 \mathrm{BAP}+0,3 \mathrm{mg} / 1 \mathrm{NAA})$.

Gambar 1. Pertumbuhan tunas iles-iles (Amorphophallus muelleri Blume) kombinasi perlakuan BAP dan NAA minggu ke-12

\section{KESIMPULAN}

Kesimpulan yang dapat diambil dari penelitian yang telah dilakukan yaitu BAP (1 dan $2 \mathrm{mg} / \mathrm{l}$ ) merupakan zat pengatur tumbuh yang paling tepat untuk mikropropagasi (perbanyakan) tangkai daun iles-iles dibuktikan dengan nilai kedinian terbentuknya kalus (B1: 25; B2: 19,11), kuantitas kalus (B1: 3,28; B2: 3,22) dan kedinian terbentuknya akar (B1: 27,44; B2: 24,83 ) yang lebih besar dari NAA.

\section{DAFTAR PUSTAKA}

Altman, A., \& Loberant, B. (1998). 尌 Micropropagation: Clonal Plant Propagation In Vitro. In A. Altman, R. Colwell, Rita, L. First, Neal, J. Schell, \& K. Vasil, Indra (Eds.),

\section{(cc) BY-SA}


Agricultural Biotechnology (pp. 1942). Marcel Dekker, Inc.

Andarwulan, N., Fardiaz, D., Wattimena, E. A., \& Shetty, K. (1999). Antioxidant activity associated with lipid and phenolic mobilization during seed germination of Pangium edule Reinw. Journal of Agricultural and Food Chemistry, 47(8), 31583163. https://doi.org/10.1021/jf9812 $87 \mathrm{a}$

Andaryani, S. (2010). Kajian Penggunaan 尌 Berbagai Konsentrasi BAP dan 2,4D Terhadap Induksi Kalus Jarak Pagar (Jatropha curcas L.) Secara In Vitro. Universitas Sebelas Maret.

Armini, N. M., Wattimena, G. A., \& 琶 Gunawan, L. W. (1992). Perbanyakan tanaman. Bioteknologi Tanaman (Vol. 1). Bogor: Pusat Antar Universitas. Universitas Pertanian Bogor.

George, E. F., \& Sherrington, P. D. (1984). 尌 Plant propagation by tissue culture. Exegetics Ltd.

Hetterscheid, W. L. A., \& Ittenbach, S. 髷 (1996). Everything You Always Wanted To Know About Amorphophallus, But Were Afraid To Stick Your Nose Into. Aroideana, 19, 7-131.

Ikeuchi, M., Sugimoto, K., \& Iwase, A. 期 (2013). Plant Callus: Mechanisms Of Induction And Repression. The Plant Cell, 25(9), 3159-3173. https:// doi.org/10.1105/tpc.113.116053

Imelda, M., Wulansari, A., \& Poerba, Y. S. 尌 (2007). Mikropropagasi Tanaman Iles-Iles (Amorphophallus muelleri Blume). Berita Biologi, 8(4). https://doi.org/10.14203/beritabiolo gi.v8i4.2117

Imelda, M., Wulansari, A., \& Poerba, Y. S. (2008). Regenerasi Tunas Dari Kultur Tangkai Daun Iles-iIes (Amorphophallus muelleri Blume). Biodiversitas, 9(3), 173-176. https://doi.org/10.13057/biodiv/d09 0304

Indah, P. N., \& Ermavitalini, D. (2013). 尌 Induksi Kalus Daun Nyamplung (Calophyllum inophyllum Linn.) pada Beberapa Kombinasi Konsentrasi 6-Benzylaminopurine (BAP) dan 2,4Dichlorophenoxyacetic Acid (2,4D). Jurnal Sains Dan Seni ITS, 2(1), E1--E6. https://doi.org/10.12962/ j23373520.v2i1.2571

Karjadi, A. K. (2016). Kultur Jaringan dan 尌 Mikropropagasi Tanaman Kentang( Solanum tuberosum L ). Bandung: Balai Penelitian Tanaman Sayuran.

Karjadi, A. K., \& Buchory, A. (2008). E Pengaruh Auksin dan Sitokinin Terhadap Pertumbuhan dan Perkembangan Jaringan Meristem Kentang Kultivar Granola. Jurnal Hortikultura, 18(4).

Nisa, C., \& Rodinah. (2005). Kultur E Jaringan Beberapa Kultivar Buah Pisang (Musa paradisiaca L.) dengan Pemberian Campuran NAA dan Kinetin. Bioscience, 2(2), 23-36.

Pierik, R. L. M. (1987). In Vitro Culture Of 尌 Higher Plants as a Tool in the Propagation of Horticultural Crops. In Proceedings: International Symposium on Propagation of Ornamental Plants 226, 1987. pp.2540. In International Symposium on Propagation of Ornamental Plants 226 (pp. 25-40). International 
Society for Horticultural Science. https://doi.org/10.17660/ActaHortic. 1988.226.1

Rahayu, B., \& Anggarwulan, E. (2003). 钢 Pengaruh Asam 2,4Diklorofenoksiasetat (2,4-D) terhadap Pembentukan dan Pertumbuhan Kalus serta Kandungan Flavonoid Kultur Kalus Acalypha indica L. Biofarmasi, 1(1), 1-6.

Turhan, H. (2004). Callus Induction and 尌 Growth in Transgenic Potato Genotypes. African Journal of Biotechnology, 3(8), 375-378. https://doi.org/10.5897/AJB2004.00 0-2072 